\title{
Digestibility and metabolic utilisation of dietary energy in adult sows: influence of addition and origin of dietary fibre
}

\author{
G. Le Goff, L. Le Groumellec, J. van Milgen, S. Dubois and J. Noblet* \\ Institut National de la Recherche Agronomique, Unité Mixte de Recherches sur le Veau et le Porc, 35590 St Gilles, France
}

(Received 4 June 2001 - Revised 29 October 2001 - Accepted 10 December 2001)

\begin{abstract}
According to a $4 \times 4$ Latin square design, four adult ovariectomised sows fed at a similar energy level $\left(516 \mathrm{~kJ} \mathrm{ME} / \mathrm{kg}\right.$ body weight $(\mathrm{BW})^{0.75}$ per d) received one of four diets successively: a control low-dietary-fibre (DF) diet (diet C, $100 \mathrm{~g}$ total DF/kg DM) and three fibrerich diets $(200 \mathrm{~g}$ total $\mathrm{DF} / \mathrm{kg} \mathrm{DM})$ that corresponded to a combination of diet $\mathrm{C}$ and maize bran (diet MB), wheat bran (diet WB), or sugar-beet pulp (diet SBP). Sows were adapted to the diet for $12 \mathrm{~d}$ before an $8 \mathrm{~d}$ measurement period. Digestibility of energy and nutrients in the diets, and total heat production (HP) and its components (fasting HP, activity HP and thermic effect of feeding (TEF), were measured. The TEF was partitioned between a short-term component $\left(\mathrm{TEF}_{\mathrm{st}}\right)$ and a long-term component $\left(\mathrm{TEF}_{\mathrm{lt}}\right)$. Total tract digestibility of nutrients and energy was greater for diet $\mathrm{C}$; among the three other diets, the digestibility coefficients were higher for diet SBP than for diets $\mathrm{MB}$ and WB. Energy losses from $\mathrm{CH}_{4}$ were linearly related to the digestible total DF intake $(+1 \cdot 4 \mathrm{~kJ} / \mathrm{g})$. Fasting HP at zero activity averaged $260 \mathrm{~kJ} / \mathrm{kg} \mathrm{BW}^{0.75}$ per d. Activity HP represented $20 \%$ total $\mathrm{HP}$, or $83 \mathrm{~kJ} / \mathrm{kg} \mathrm{BW}^{0.75}$ per d on average. Total TEF and $\mathrm{TEF}_{\mathrm{lt}}$ were higher $(P<0 \cdot 05)$ for diet $\mathrm{WB}$ than for the other diets. However, total HP $\left(406 \mathrm{~kJ} / \mathrm{kg} \mathrm{BW}^{0.75}\right.$ per d) was not significantly affected by diet characteristics. Our results suggest that metabolic utilisation of dietary energy is little affected by the addition and origin of DF, at least under the conditions of the present study.
\end{abstract}

Sows: Heat production: Energy value: Dietary fibre

Under commercial conditions, pregnant sows are given restricted amounts of feed in order to maintain optimal body condition and productivity (Whittemore et al. 1988). Whilst restrictive feeding is advantageous for both health and economic reasons, feed restriction has been identified as an important predisposing factor in the development of stereotypic behaviours in sows (Lawrence \& Terlouw, 1993). Therefore, high-fibre diets have been recommended in order to improve welfare of sows by reducing their feeding motivation without compromising productivity (Brouns et al. 1995). In addition, increased availability of fibre-rich ingredients from, for instance, the feed milling or starch extraction or fermentation industries, favoured the increased utilisation of fibre-rich ingredients in pig feeds.

The effect of dietary fibre (DF) on digestibility of energy and nutrients has been investigated in several studies in growing pigs (Graham et al. 1986; Chabeauti et al.
1991), adults sows (Etienne, 1987; Ramonet et al. 1999) or both (Noblet \& Shi, 1993; Etienne et al. 1997). The digestibility of DF is greater in adult sows compared with growing pigs, partly due to a more developed digestive system in adult animals (Noblet \& Shi, 1993). The metabolic utilisation of fibre-rich diets has been studied more recently. The statistical approach used by Noblet et al. (1993a) to establish net energy prediction equations showed an increased heat increment when the fibre level of the diet was increased in adult sows. However, these results were not sufficiently accurate to be extrapolated to all situations. The effect of the level of DF on metabolic utilisation of diet, as measured in growing pigs (Jørgensen et al. 1996) or in adult sows (Ramonet et al. 2000), confirmed the results obtained by Noblet et al. (1993a). On the other hand, other results did not show greater heat production (HP) in animals fed high-fibre diets (Schrama et al. 1996; Rijnen et al. 2001). Therefore, the effect of DF on

\footnotetext{
Abbreviations: BW, body weight; DC, digestibility coefficient; DE, digestible energy; Diet C, control diet; Diet MB, maize-bran supplemented diet; Diet SBP, sugar-beet-pulp supplemented diet; Diet WB, wheat-bran supplemented diet; DF, dietary fibre; HP, heat production; ME, metabolisable energy; $\mathrm{ME}_{\mathrm{m}}$, metabolisable energy requirement for maintenance; $\mathrm{NE}$, net energy; TEF, $\mathrm{TEF}_{\mathrm{lt}}, \mathrm{TEF}_{\mathrm{st}}$, total, long-term and short-term thermic effect of feeding, respectively.

* Corresponding author: Dr J. Noblet, fax +332234850 80, email noblet@st-gilles.rennes.inra.fr
} 
energy expenditure and partitioning of HP merits further study.

The objective of the present study was to quantify the effect of addition and botanical origin of DF (maize, wheat, sugar beet) on digestibility and metabolic utilisation of dietary energy and components of HP in adult non-lactating, non-gestating sows.

\section{Materials and methods}

\section{Experimental design}

Four Large White $\times$ Landrace sows (mean live weight $230 \mathrm{~kg}$ ) were assigned to four dietary treatments in a repeated $4 \times 4$ Latin square design. Sows were ovariectomised in order to avoid any effect of cycling and oestrus on HP measurements. Care and use of animals were performed according to the Certificate of Authorisation to Experiment on Living Animals, no. 04739 (delivered by the French Ministry of Agriculture to J. Noblet). Each sow received alternately one of four experimental diets during four successive $20 \mathrm{~d}$ periods. During each period, sows were adapted to the diet for $12 \mathrm{~d}$ and subsequently moved to metabolism cages for collection of faeces and urine for $8 \mathrm{~d}$. During the $8 \mathrm{~d}$ excreta-collection period, each metabolism cage was in a respiration chamber so as to measure gas exchanges $\left(\mathrm{O}_{2}, \mathrm{CO}_{2}\right.$ and $\left.\mathrm{CH}_{4}\right)$ continuously. Sows were kept in the respiration chambers for one additional day in order to estimate fasting HP. Two chambers were used simultaneously, which allowed measurement of digestibility and energy balances in four sows over a 3 -week period.

The four diets differed in their DF content. The control diet (diet C) contained a low level of DF (100 g total DF/ $\mathrm{kg}$ DM) and was prepared from wheat and isolated soyabean proteins. The other diets corresponded to a combination of the control diet and maize bran (diet MB), wheat bran (diet WB), or sugar-beet pulp (diet SBP) and were formulated to contain the same level of DF (200 g total DF/ $\mathrm{kg}$ DM). Ingredient composition and chemical characteristics of diets are reported in Table 1. During the study, sows received their diet in two meals (09.00 and 17.00 hours) as pellets (diameter $4.5 \mathrm{~mm}$; pelleting at about $60^{\circ} \mathrm{C}$ ). Feeding level of each sow was adjusted for each period to provide the same daily metabolisable energy $(\mathrm{ME}) / \mathrm{kg}$ metabolic body weight (BW) $\left(500 \mathrm{~kJ} / \mathrm{kg} \mathrm{BW} \mathrm{BW}^{0.75}\right.$ per d). Water was available ad libitum throughout the experimental period.

The open-circuit respiration chambers had a volume of approximately $12 \mathrm{~m}^{3}$ and are based on a design similar to that of Vermorel et al. (1973). The temperature was maintained at $24 \cdot 0 \pm 0 \cdot 1{ }^{\circ} \mathrm{C}$ and relative humidity was $70 \%$; this ambient temperature is supposed to be within the thermoneutral zone of adult sows, even when fasted (Noblet et al. 1989). Light was on between 08.15 and 20.15 hours. Each chamber contained an individual metabolism cage equipped with two infrared beams to detect standing or sitting positions of the animal. Interruption of an infrared beam for at least $20 \mathrm{~s}$ was considered to be physical activity (i.e. standing or sitting) of the animal. In addition,

Table 1. Composition of experimental diets

\begin{tabular}{lcccc}
\hline Diets & C & MB & WB & SBP \\
\hline Components (g/kg diet) & & & & \\
Wheat & 899 & $680 \cdot 9$ & $647 \cdot 7$ & $762 \cdot 4$ \\
Isolated soyabean proteins & $68 \cdot 5$ & $51 \cdot 9$ & $49 \cdot 3$ & $58 \cdot 1$ \\
Maize bran & - & $234 \cdot 7$ & - & - \\
Wheat bran & - & - & $270 \cdot 5$ & - \\
Sugar-beet pulp & - & - & - & $147 \cdot 0$ \\
Dicalcium phosphate & $12 \cdot 0$ & $12 \cdot 0$ & $12 \cdot 0$ & $12 \cdot 0$ \\
Calcium carbonate & $11 \cdot 0$ & $11 \cdot 0$ & $11 \cdot 0$ & $11 \cdot 0$ \\
Salt & $4 \cdot 5$ & $4 \cdot 5$ & $4 \cdot 5$ & 4.5 \\
Vitamins and minerals mixture* & $5 \cdot 0$ & $5 \cdot 0$ & $5 \cdot 0$ & $5 \cdot 0$ \\
Chemical composition (g/kg DM) & & & & \\
Ash & 49 & 51 & 61 & 58 \\
Crude protein (N $\times 6 \cdot 25)$ & 171 & 168 & 170 & 160 \\
Diethyl ether extract & 16 & 23 & 23 & 15 \\
Crude fibre & 27 & 46 & 46 & 51 \\
NDF & 107 & 197 & 196 & 158 \\
ADF & 28 & 51 & 56 & 55 \\
ADL & 8 & 10 & 15 & 8 \\
Total DF & 103 & 197 & 197 & 183 \\
WICW & 106 & 195 & 199 & 171 \\
Starch & 596 & 516 & 481 & 541 \\
Sugars & 28 & 22 & 39 & 30 \\
Gross energy (MJ/kg DM) & $17 \cdot 97$ & $18 \cdot 19$ & $18 \cdot 04$ & $17 \cdot 71$ \\
\hline
\end{tabular}

C, control diet; MB, maize-bran supplemented diet; WB, wheat-bran supplemented diet; SBP, sugar-beet-pulp supplemented diet; NDF, neutral-detergent fibre; ADF, acid-detergent fibre; ADL, acid-detergent lignin; DF, dietary fibre; WICW, water-insoluble cell walls.

*Vitamins and minerals mixture provided the following (/kg diet): retinyl palmitate $2.7 \mathrm{mg}$, cholecalciferol $25 \mu \mathrm{g}$, DL- $\alpha$-tocopherol acetate $20.0 \mathrm{mg}$, thiamin $2.0 \mathrm{mg}$, riboflavin $4.0 \mathrm{mg}$, pyridoxine $1.0 \mathrm{mg}$, cobalamin $20 \mu \mathrm{g}$, niacin $15 \mathrm{mg}$, D-panthotenate $9.9 \mathrm{mg}$, biotin $200 \mu \mathrm{g}$, folic acid $1 \mathrm{mg}$, menadione $2.0 \mathrm{mg}$, choline chloride $500 \mathrm{mg}, \mathrm{Zn} 80.5 \mathrm{mg}$, Cu $4.0 \mathrm{mg}, \mathrm{Mn}$ $28.6 \mathrm{mg}$, Fe $38.5 \mathrm{mg}, \mathrm{I} 131 \mu \mathrm{g}$, Co $38.0 \mu \mathrm{g}$, Se $38.5 \mu \mathrm{g}$. 
the metabolism cage was placed on four force sensors (type 9104A; Kistler, Winterthur, Switzerland), which produced an electric signal assumed to be proportional to the physical activity of the animal. The weight of the trough was measured continuously by a load cell.

\section{Measurements}

Sows were weighed at the beginning of each collection period. For each diet and each sow, a sample of feed was collected and measured for its DM content; samples of each diet were subsequently pooled for chemical analyses. Faeces were collected daily, stored at $4^{\circ} \mathrm{C}$ and weighed, homogenised and subsampled at the end of the period. One faeces sample was heat-dried for DM determination and a second was freeze-dried for further chemical analyses. Urine was collected daily, weighed and an aliquot was taken; aliquots of samples from each animal were combined. The $\mathrm{N}_{2}$ losses in the air, which were recovered in condensed water and in out-going air from the respiration chamber were measured according to the method described by Noblet et al. (1993a).

For feed samples, the methods of the Association of Official Analytical Chemists (1990) were used for measuring moisture, ash, crude protein $(\mathrm{N} \times 6 \cdot 25)$, Weende crude fibre, and diethyl ether extract. Gross energy content was measured using an adiabatic bomb calorimeter (IKA, Staufen, Germany). Cell-wall fractions (neutral-detergent fibre, acid-detergent fibre and acid-detergent lignin) were determined according to the methods of Van Soest \& Wine (1967) by using a sequential procedure with prior amylolytic treatment. Total DF contents were quantified according to the method of Prosky et al. (1988), and water-insoluble cell walls according to the method of Carré \& Brillouet (1986). Starch content was determined using the Ewer's polarimetric method (European Economic Community, 1972), and the content of sugars corresponded to alcohol-soluble carbohydrates obtained by the method of Luff-Schoorl (Bureau Interprofessionel d'Etudes Analytiques, 1976). Moisture, ash, crude protein, cell-wall fractions and gross energy analyses were carried out on each faecal sample. In addition, diethyl ether extract after $\mathrm{HCl}$ hydrolysis was measured on pooled samples of faeces (one per diet). $\mathrm{N}$ in urine was analysed on fresh material, whereas energy content was obtained after freeze-drying approximately $30 \mathrm{ml}$ urine in polyethylene bags. Analyses on feed samples were performed in triplicate, while analyses on excreta were performed in duplicate.

Every $10 \mathrm{~s}$, mean values for $\left[\mathrm{O}_{2}\right],\left[\mathrm{CO}_{2}\right]$ and $\left[\mathrm{CH}_{4}\right]$ and temperature and ventilation rate in the respiration chamber were recorded as described by van Milgen et al. (1997). Over the same time-span, the signal of the force sensors was recorded. When the weight of the trough was detected as unstable, the corresponding beginning and ending time and the change in weight of the trough were recorded. Measurements of gas concentration, signals of the force sensors and weight of the trough were stored on a microcomputer awaiting further calculations.

\section{Calculations and statistical analysis}

Apparent digestibility coefficients (DC) of organic matter, nutrients and energy and digestible energy (DE) were calculated using routine procedures (Noblet \& Shi, 1994). According to Graham et al. (1986) and Bach Knudsen \& Hansen (1991), starch and sugars can be assumed to be $100 \%$ digestible at the faecal level. The ME corresponded to the difference between DE intake and energy losses in urine and $\mathrm{CH}_{4}$. The four diets were formulated in order to calculate total tract DC of nutrients and energy values of the fibre-rich ingredients according to the difference method (Noblet \& Shi, 1994). It was assumed that, for each sow, the energy and nutrient digestibility of the basal diet (diet $\mathrm{C}$ ) was constant in all diets.

$\mathrm{N}$ retention was calculated as the difference between $\mathrm{N}$ intake and $\mathrm{N}$ losses in faeces, urine, condensed water, and out-going air. The RER was calculated as the $\mathrm{CO}_{2}$ production: $\mathrm{O}_{2}$ consumption. Daily total $\mathrm{HP}$ was calculated from gas exchanges, including $\mathrm{CH}_{4}$ production, according to the formula of Brouwer (1965). The retained energy corresponded to the difference between $\mathrm{ME}$ intake and total HP. Energy retained as protein was calculated from $\mathrm{N}$ retention $(\mathrm{N} \times 6.25 \times 23.8 \mathrm{~kJ} / \mathrm{g})$, whereas energy retained as lipid corresponded to the difference between retained energy and energy retained as protein.

The components of HP were estimated daily for each sow according to the model proposed by van Milgen et al. (1997) and described by Ramonet et al. (2000). In practice, the model provides estimates of gas exchanges due to resting (litres/min), physical activity (litres/unit of force), and feed intake (litres/g). Subsequently, the corresponding unitary HP were calculated from the respective $\mathrm{O}_{2}$ consumption and $\mathrm{CO}_{2}$ production as described by Brouwer (1965), excluding the correction for urinary and $\mathrm{CH}_{4}$ production. The major components of the model are the activity $\mathrm{HP}$, the fasting $\mathrm{HP}$, the short-term thermic effect of feeding $\left(\mathrm{TEF}_{\mathrm{st}}\right)$ and the long-term thermic effect of feeding $\left(\mathrm{TEF}_{\mathrm{lt}}\right)$. Ingestion, digestion and absorption can be considered as components of the $\mathrm{TEF}_{\text {st }}$, while $\mathrm{TEF}_{1 \mathrm{t}}$ is indicative for the energy expenditure due to long-term metabolic processes such as fermentation and metabolism of nutrients. The so-called 'ghost' effect characterised by a nocturnal increase in total HP not related to feed or physical activity was included in the $\mathrm{TEF}_{\mathrm{st}}$ (van Milgen \& Noblet 2000); the 'ghost' effect represented on average 1.3 (range $0.5-2.0$ ) \% total HP. The total TEF then corresponds to the sum of $\mathrm{TEF}_{\mathrm{st}}$ and $\mathrm{TEF}_{\mathrm{lt}}$ (Ramonet et al. 2000). The distribution of daily activity HP between eating, standing and lying periods was calculated as the product of activity HP (kJ/unit of force) and the total force measured during these periods. Components of total HP were estimated for each day of measurement and values were averaged for each sow for each diet. In the subsequent calculations, the mean of daily variables was used for each sow at each experimental period.

A total of sixteen experimental periods was carried out with eight measurement days for each period. However, the first day of each experimental period and days when a technical problem occurred or modelling was impossible (i.e. twelve days out of the 128 experimental days) were 
not included in the calculation of total HP and its components over the measurement period. Consequently, total HP was calculated on seven days for nine experimental periods, six days for three experimental periods, five days for three experimental periods and four days for one experimental period. The net energy (NE, kJ/d) was calculated as $100 \times \mathrm{NE} /(\mathrm{ME}-$ activity HP), according to the approach of Noblet et al. (1993a). The efficiency of using ME for net energy $(k)$ was calculated as $(\mathrm{NE}: \mathrm{ME}) \times 100-$ activity HP. Finally, NE (kJ/kg DM) was calculated as $(\mathrm{ME}(\mathrm{kJ} / \mathrm{kg} \mathrm{DM}) \times k) / 100$. These calculations were carried out on each balance period ( $n$ 16). The final DE, ME and $\mathrm{NE}$ values of each diet corresponded to the mean of the four measurements carried out on each diet. Energy balance data were expressed as $\mathrm{kJ} / \mathrm{kg} \mathrm{BW}^{0 \cdot 75}$ per $\mathrm{d}$.

Data were submitted to an ANOVA with diet $(n 4)$, animal ( $n$ 4) and period ( $n$ 4) as the main effects; the ANOVA was completed by a contrast analysis. Energy values and DC obtained for ingredients were also submitted to ANOVA with ingredient ( $n$ 3), animal ( $n$ 4) and period ( $n 4)$ as main effects, since these were measured in each sow during the four experimental periods. The relationship between $\mathrm{CH}_{4}$ energy losses and digestible total DF was analysed according to a covariance model with digestible total DF as a covariate and sow as a fixed effect. In addition, the energy cost of standing activity was estimated from a linear regression model. The GLM procedures of Statistical Analysis Systems (SAS/STAT User's Guide, version 6, 4th ed., 1990; Cary, NC, USA) were used for all statistical analyses.

\section{Results}

According to the experimental design and as shown in Table 1, diets $\mathrm{MB}, \mathrm{WB}$, and SBP contained a higher total DF level (197, 197 and $183 \mathrm{~g} / \mathrm{kg}$ DM, respectively) than diet $\mathrm{C}(107 \mathrm{~g} / \mathrm{kg} \mathrm{DM})$. The mean $\mathrm{BW}$ of the sows during the balance experiment was $238 \mathrm{~kg}$ and was not significantly different between diets, but was affected $(P<0 \cdot 01)$ by the experimental period (Table 2$)$ in connection with a small but steady BW gain over the experiment $(240 \mathrm{~g} / \mathrm{d})$. According to the design of the experiment and as shown in Table 3, the sows were fed the same ME level during the experimental period (mean value $516 \mathrm{~kJ} / \mathrm{kg}$ $\mathrm{BW}^{0.75}$ per d). However, ME supplies were calculated according to estimated values of feeds and were greater than the expected value $\left(500 \mathrm{~kJ} / \mathrm{kg} \mathrm{BW} \mathrm{BW}^{0.75}\right.$ per $\left.\mathrm{d}\right)$ for diets $\mathrm{C}, \mathrm{WB}$ and SBP; only ME supply for diet MB corresponded to the expected value. Feed intake increased over successive periods in relation to variation in $\mathrm{BW}$ of sows over the experiment (Table 2).

Table 2. Digestive utilisation of diets and nitrogen balance in adult sows

\begin{tabular}{|c|c|c|c|c|c|c|c|c|}
\hline \multirow[b]{2}{*}{ Item } & \multicolumn{4}{|c|}{ Diet } & \multirow[b]{2}{*}{ RSD } & \multicolumn{3}{|c|}{$P$-value for main effects $†$} \\
\hline & C & MB & WB & SBP & & Animal & Diet & Period \\
\hline No. of observations & 4 & 4 & 4 & 4 & & & & \\
\hline Body weight $(\mathrm{kg})$ & 235 & 239 & 238 & 238 & 2 & $<0.001$ & NS & $<0.001$ \\
\hline DM intake $(\mathrm{g} / \mathrm{d})$ & 1989 & 2044 & 2221 & 2056 & 40 & NA & NA & NA \\
\hline \multicolumn{9}{|l|}{ Digestibility coefficient (\%) } \\
\hline DM & $92 \cdot 0^{\mathrm{a}}$ & $87 \cdot 1^{\mathrm{c}}$ & $84 \cdot 2^{d}$ & $88 \cdot 8^{\mathrm{b}}$ & 0.9 & NS & $<0.001$ & NS \\
\hline Organic matter & $94 \cdot 0^{\mathrm{a}}$ & $89 \cdot 5^{\mathrm{c}}$ & $87 \cdot 1^{d}$ & $91 \cdot 7^{\mathrm{b}}$ & 0.8 & NS & $<0.001$ & NS \\
\hline Crude protein & $92 \cdot 2^{\mathrm{a}}$ & $85 \cdot 0^{\mathrm{d}}$ & $86 \cdot 1^{\mathrm{c}}$ & $87 \cdot 6^{\mathrm{b}}$ & 0.5 & $<0.001$ & $<0.001$ & 0.004 \\
\hline Diethyl ether extract & 63 & 52 & 49 & 38 & NA & NA & NA & NA \\
\hline Crude fibre & $55^{\mathrm{a}}$ & $55^{\mathrm{a}}$ & $36^{\mathrm{b}}$ & $66^{\mathrm{a}}$ & 9 & NS & 0.024 & NS \\
\hline NDF & $70^{\mathrm{a}}$ & $72^{\mathrm{a}}$ & $60^{\mathrm{b}}$ & $74^{\mathrm{a}}$ & 4 & NS & 0.012 & NS \\
\hline ADF & $51^{\mathrm{b}}$ & $59^{a}$ & $39^{\mathrm{b}}$ & $66^{\mathrm{a}}$ & 9 & NS & 0.021 & NS \\
\hline Total DF & $67^{\mathrm{a}}$ & $69^{\mathrm{a}}$ & $58^{\mathrm{b}}$ & $74^{\mathrm{a}}$ & 5 & NS & 0.013 & NS \\
\hline Energy & $92.8^{\mathrm{a}}$ & $87.4^{\mathrm{C}}$ & $85.0^{\mathrm{d}}$ & $90 \cdot 0^{\mathrm{b}}$ & 0.9 & NS & $<0.001$ & NS \\
\hline Methane (litres/d) & $6 \cdot 1^{\mathrm{b}}$ & $11 \cdot 1^{\mathrm{a}}$ & $7 \cdot 4^{\mathrm{b}}$ & $9 \cdot 9^{a}$ & 1.4 & $<0.001$ & 0.007 & NS \\
\hline Energy as methane (\% DE) & $0.88^{b}$ & $1.33^{\mathrm{a}}$ & $0.85^{b}$ & $1 \cdot 19^{a, b}$ & 0.25 & 0.024 & 0.072 & NS \\
\hline Energy in urine (\% DE) & 4.90 & $5 \cdot 35$ & $4 \cdot 29$ & 3.50 & $1 \cdot 1$ & NS & NS & NS \\
\hline ME/DE (\%) & 94.2 & 93.3 & 94.9 & $95 \cdot 3$ & 1.2 & NS & NS & NS \\
\hline \multicolumn{9}{|l|}{ Nitrogen balance $(\mathrm{g} / \mathrm{d})$} \\
\hline Intake & $54 \cdot 6^{\mathrm{b}, \mathrm{c}}$ & $54 \cdot 9^{\mathrm{b}}$ & $60 \cdot 5^{a}$ & $52 \cdot 7^{\mathrm{c}}$ & $1 \cdot 1$ & 0.032 & $<0.001$ & 0.012 \\
\hline \multicolumn{9}{|l|}{ Losses } \\
\hline In faeces & $4 \cdot 2^{c}$ & $8 \cdot 3^{a}$ & $8 \cdot 5^{\mathrm{a}}$ & $6 \cdot 6^{b}$ & 0.3 & 0.002 & $<0.001$ & 0.001 \\
\hline In urine and gas & 44.5 & 38.5 & 44.2 & 37.7 & 4.5 & NS & NS & NS \\
\hline Total & $48 \cdot 7$ & $46 \cdot 8$ & $52 \cdot 7$ & $44 \cdot 3$ & 4.5 & NS & NS & NS \\
\hline Retention & 5.9 & 8.0 & 7.8 & 8.4 & $7 \cdot 3$ & NS & NS & NS \\
\hline
\end{tabular}

C, control diet; MB, maize-bran supplemented diet; WB, wheat-bran supplemented diet; SBP, sugar-beet-pulp supplemented diet; RSD, residual standadard error; NDF, neutral-detergent fibre; ADF, acid-detergent fibre, DF, dietary fibre; DE, digestible energy; ME, metabolisable energy; NA, not applicable.

a,b,c,d Mean values within a row with unlike superscript letters were significantly different, $(P<0.05)$.

${ }^{*}$ For details of diets and procedures, see Table 1 and p. 326.

†From ANOVA with effects of diet $(n 4)$, animal $(n 4)$ and period $(n 4)$. Diethyl ether extract of faeces was measured on samples pooled per diet and per pig stage and corresponding digestibility coefficients could not be submitted to the ANOVA. Starch was considered as $100 \%$ digestible. 
Table 3. Effect of diet composition on heat production and energy balance in adult sows*

\begin{tabular}{|c|c|c|c|c|c|c|c|c|}
\hline \multirow[b]{2}{*}{ Item } & \multicolumn{4}{|c|}{ Diet } & \multirow[b]{2}{*}{ RSD } & \multicolumn{3}{|c|}{$P$-value for main effects $\dagger$} \\
\hline & $\mathrm{C}$ & MB & WB & SBP & & Animal & Diet & Period \\
\hline \multirow{2}{*}{\multicolumn{9}{|c|}{ Energy balance $\left(\mathrm{kJ} / \mathrm{kg} \mathrm{BW} \mathrm{BW}^{0.75}\right.$ per d) }} \\
\hline & & & & & & & & \\
\hline $\mathrm{DE}$ & $553^{a, b}$ & $534^{\mathrm{b}}$ & $558^{a}$ & $539^{a, b}$ & 12 & NS & 0.088 & NS \\
\hline ME & 521 & 499 & 529 & 514 & 16 & NS & NS & NS \\
\hline \multicolumn{9}{|l|}{ Heat production } \\
\hline As fasting HP & 256 & 268 & 256 & 260 & 10 & 0.019 & NS & NS \\
\hline \multicolumn{8}{|l|}{ As TEF } & NS \\
\hline TEF $_{\text {st }}$ & 63 & 56 & 57 & 59 & 5 & 0.057 & NS & NS \\
\hline $\mathrm{TEF}_{\mid \mathrm{t}}$ & 2 & -3 & 18 & 0 & 10 & 0.016 & 0.074 & 0.026 \\
\hline Total & $65^{\mathrm{b}}$ & $52^{\mathrm{C}}$ & $75^{\mathrm{a}}$ & $59^{\mathrm{bc}}$ & 6 & 0.010 & 0.006 & 0.002 \\
\hline As resting HP¥ & 322 & 321 & 331 & 319 & 11 & 0.029 & NS & NS \\
\hline Total HP & 404 & 403 & 412 & 405 & 8 & $<0.001$ & NS & 0.015 \\
\hline \multicolumn{9}{|l|}{ Retained energy } \\
\hline As protein & 14 & 20 & 19 & 21 & 13 & NS & NS & NS \\
\hline As lipid & $102^{\mathrm{a}}$ & $76^{\mathrm{C}}$ & $98^{\mathrm{a}}$ & $88^{\mathrm{b}}$ & 5 & $<0.001$ & 0.002 & 0.003 \\
\hline Total & 116 & 96 & 117 & 109 & 15 & $<0.001$ & NS & NS \\
\hline \multicolumn{9}{|c|}{ Thermic effect of feeding (\% ME intake) } \\
\hline $\mathrm{TEF}_{\mathrm{st}}$ & $12 \cdot 0$ & 11.3 & $10 \cdot 7$ & 11.5 & $1 \cdot 1$ & 0.048 & NS & NS \\
\hline TEF $_{\mathrm{It}}$ & 0.3 & -0.5 & $3 \cdot 3$ & 0.0 & $1 \cdot 8$ & 0.018 & 0.100 & 0.023 \\
\hline Total & $12 \cdot 5^{\mathrm{ab}}$ & $10 \cdot 5^{\mathrm{c}}$ & $14 \cdot 0^{\mathrm{a}}$ & $11 \cdot 5^{\mathrm{bc}}$ & 1.0 & 0.004 & 0.010 & $<0.001$ \\
\hline RER & 1.04 & 1.03 & 1.05 & 1.04 & 0.02 & $<0.001$ & NS & NS \\
\hline \multicolumn{9}{|l|}{ Energy utilisation (\%) } \\
\hline NE/ME§ & $86 \cdot 0$ & $85 \cdot 4$ & $84 \cdot 3$ & $86 \cdot 3$ & $2 \cdot 1$ & NS & NS & NS \\
\hline NE/DE§ & 81.0 & $79 \cdot 7$ & 79.9 & 82.3 & 2.5 & NS & NS & NS \\
\hline \multicolumn{9}{|c|}{ Energy values (MJ/kg DM) } \\
\hline DE & $16 \cdot 67^{a}$ & $15 \cdot 89^{b}$ & $15 \cdot 33^{c}$ & $15 \cdot 94^{\mathrm{b}}$ & 0.17 & NS & $<0.001$ & NS \\
\hline ME & $15 \cdot 71^{\mathrm{a}}$ & $14 \cdot 82^{\mathrm{bc}}$ & $14.54^{\mathrm{C}}$ & $15 \cdot 19^{\mathrm{b}}$ & 0.23 & NS & $<0.001$ & NS \\
\hline NE§ & $13.51^{a}$ & $12.66^{\mathrm{bc}}$ & $12 \cdot 25^{\mathrm{c}}$ & $13 \cdot 11^{\mathrm{ab}}$ & 0.40 & NS & 0.020 & NS \\
\hline
\end{tabular}

C, control diet; MB, maize-bran supplemented diet; WB, wheat-bran supplemented diet; SBP, sugar-beet-pulp supplemented diet; RSD, residual standard deviation; $\mathrm{DE}$, digestible energy; ME, metabolisable energy; $\mathrm{HP}$, heat production; $\mathrm{TEF}, \mathrm{TEF}_{\mathrm{lt}}, \mathrm{TEF}_{\mathrm{st}}$, total, long-term and short-term thermic effect of feeding respectively; NE, net energy.

a,b,c,d Mean values within a row with unlike superscript letters were significantly different, $P<0.05$.

For details of diets and procedures, see Table 1 and p. 326.

†From ANOVA with effects of diet $(n 4)$, animal $(n 4)$ and period $(n 4)$.

‡Resting HP = total HP - activity HP.

$\S N E=M E$ - activity HP - TEF with TEF = HP - activity HP - fasting HP; fasting HP is a mean value for each sow over the four experimental periods. The NE:ME is calculated as NE/(ME - activity HP) according to Noblet et al. (1993a).

\section{Effect of diet composition on digestibility of dietary energy and nutrients and nitrogen balance in adult sows}

Total tract DC of DM, organic matter and energy differed significantly between diets, with the greatest DC $(P<0 \cdot 01)$ obtained for diet $\mathrm{C}$, which contained the lowest amount of cell-wall fractions according to the contrast analysis (result not shown). Among the three other diets, the DC of DM, organic matter, and energy were greater $(P<0 \cdot 01)$ for diet SBP than for diets MB and WB (Table 2). Similarly, lower total tract DC for crude protein $(P<0.01)$ were measured in diets with a high-fibre level when compared with the diet $\mathrm{C}$ according to the contrast analysis (result not shown). In addition, results in Table 2 show that the digestibility of crude protein differed between sows $(P<0.01)$ and was affected by the experimental period $(P<0.01)$. DC of crude fat were variable (range $38-$ $63 \%$ ), the lowest value being determined in diet SBP that contained the lower crude fat level. DC of plant cellwall fractions varied according to the criteria used for their estimation (i.e. crude fibre, neutral-detergent fibre, acid-detergent fibre, acid-detergent lignin and total DF). Nevertheless, the DC of DF differed between diets, being lower $(P<0.05)$ for the diet that contained DF from wheat bran than for diets that contained maize bran or sugar-beet pulp. As a result of differences in DM intake and DC between diets, digestible DF (neutral-detergent fibre or total DF) intake was 2-fold higher $(P<0.01)$ for diets $\mathrm{MB}, \mathrm{WB}$ and SBP than for diet $\mathrm{C}$ (Table 2). Diet composition also affected $(P<0 \cdot 01)$ the daily $\mathrm{CH}_{4}$ production, which represented about $1.1 \%$ DE intake (Table 3). In fact, $\mathrm{CH}_{4}$ energy losses were linearly related to the digestible fibre intake with a $1.4 \mathrm{~kJ}$ increase of $\mathrm{CH}_{4}$ energy for each additional $g$ digestible total DF in the diet (Fig. 1). However, the $\mathrm{CH}_{4}$ production was highly variable between sows (Table 2, Fig. 1), with a mean difference of $250 \mathrm{~kJ} / \mathrm{d}$ between the lowest and the highest $\mathrm{CH}_{4}$ energy loss (individual results not shown). Energy content of urine represented on average $4.8 \% \mathrm{DE}$ and was not affected by diet composition. Finally, in connection with variations in the gross energy content (Table 1) and DC of energy (Table 2), the DE values of diets $\mathrm{MB}$ and SBP were $0.8 \mathrm{MJ} / \mathrm{kg} \mathrm{DM}$ lower $(P<0 \cdot 01)$ than the value of diet $\mathrm{C}$, and the DE value of diet WB was $1.4 \mathrm{MJ} / \mathrm{kg} \mathrm{DM}$ lower $(P<0.01)$ than the DE value of diet C (Table 3$)$.

In connection with variation in crude protein content of 


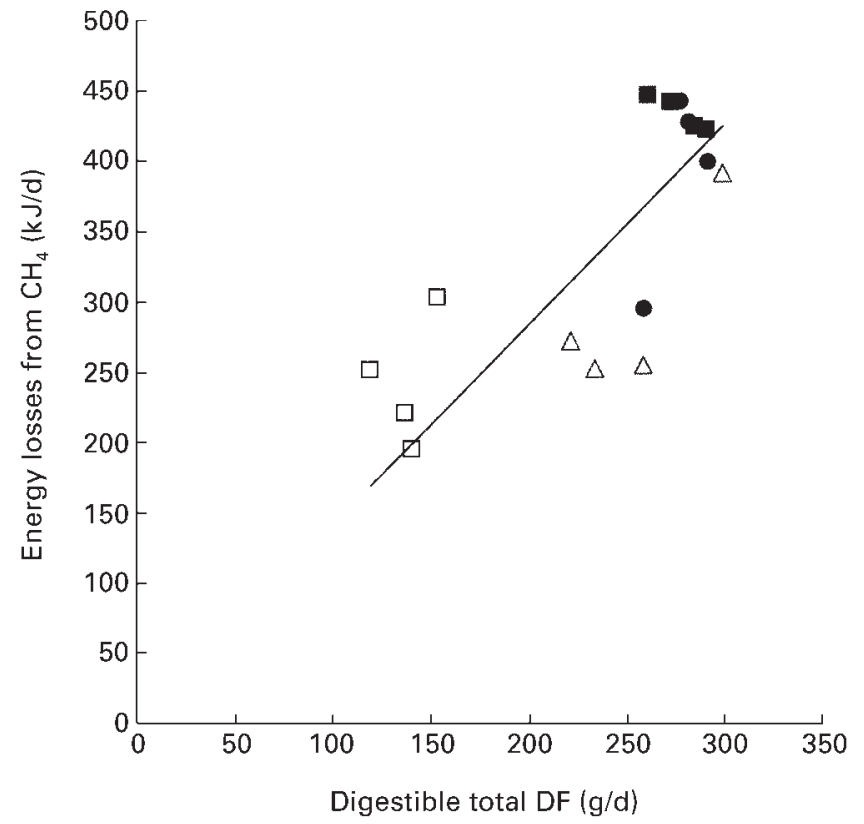

Fig. 1. Relationship between energy losses from methane and digestible total dietary fibre (DF) in adult sows $(y=1.42$ (SE 0.06) $x, R^{2}$ 0.56). ( $\square$ ), Control diet; ( $\square$ ), maize-bran supplemented diet; $(\triangle)$, wheat-bran supplemented diet; $(\bullet)$, sugar-beet-pulp supplemented diet. For details of diets and procedures, see Table 1 and p. 326. Results were adjusted for the animal effect (covariance analysis).

the diets (Table 1) and DM intake (Table 2), the $\mathrm{N}$ intake was greater $(P<0 \cdot 01)$ for diet WB than for diet $\mathrm{C}$ or $\mathrm{MB}$ and diet SBP (Table 2). Faecal losses of $\mathrm{N}$ were higher $(P<0.01)$ for diets that contained high amounts of DF, while the $\mathrm{N}$ losses in urine and gases were not affected by diet composition. Finally, the $\mathrm{N}$ retention was low (mean value $7 \mathrm{~g} / \mathrm{d}$ ), and it was not affected by diet composition.

\section{Effect of diet composition on energy balance in adult sows}

The partitioning of HP indicates that the fasting HP (at zero physical activity) was the main component of total HP, which represented between 48 and $54 \% \mathrm{ME}$ intake; (mean value $260 \mathrm{~kJ} / \mathrm{kg} \mathrm{BW} \mathrm{BW}^{0.75}$ per $\mathrm{d}$ for the four diets (Table 3)). The remainder was due to activity HP and TEF $\left(83\right.$ and $63 \mathrm{~kJ} / \mathrm{kg} \mathrm{BW} \mathrm{BW}^{0.75}$ per $\mathrm{d}$ on average for the four diets respectively). Neither the fasting HP, nor the activity HP were affected by diet composition $(P>0 \cdot 05)$. On the other hand, the TEF was affected by diet composition $(P<0 \cdot 01)$, with a higher value for diet WB $(75 \mathrm{~kJ} /$ $\mathrm{kg} \mathrm{BW}{ }^{0.75}$ per d) than for diets $\mathrm{C}, \mathrm{SBP}$, and $\mathrm{MB}(65,59$ and $52 \mathrm{~kJ} / \mathrm{kg} \mathrm{BW}^{0.75}$ per d respectively). The variation in TEF between diets was mainly due to the long-term component of TEF $\left(\mathrm{TEF}_{1 \mathrm{l}}\right)$. According to the contrast analysis (result not shown), the $\mathrm{TEF}_{\mathrm{lt}}$ was higher $(P<0.05)$ for diet $\mathrm{WB}$ than for the other three diets; the $\mathrm{TEF}_{\mathrm{lt}}$ for diets $\mathrm{C}, \mathrm{MB}$ and SBP was not different from zero $(P>0.05)$. The short-term component of TEF $\left(\mathrm{TEF}_{\mathrm{st}}\right)$ was relatively constant between diets (Table 3 ). In relation to the absence of an effect of diet composition on the main components of
$\mathrm{HP}$ (i.e. fasting $\mathrm{HP}$, activity $\mathrm{HP}$ and $\mathrm{TEF}_{\mathrm{st}}$ ), resting $\mathrm{HP}$ and total HP were similar between diets $(P>0.05)$. In other words, addition of DF between diet $\mathrm{C}$ and the other three diets had no effect $(P>0.05)$ on daily total HP irrespective of the origin of dietary fibre (i.e. maize bran, wheat bran or sugar-beet pulp). In connection with similar ME intake and $\mathrm{HP}$ values between diets, the NE:ME ratio was not affected by the DF level. Similarly, the energy retention was not affected by diet composition. The energy retained as protein was low $\left(14-20 \mathrm{~kJ} / \mathrm{kg} \mathrm{BW} \mathrm{BW}^{0.75}\right.$ per d). In fact, the results show that energy was mostly retained as lipid $\left(95-117 \mathrm{~kJ} / \mathrm{kg} \mathrm{BW} \mathrm{BW}^{0.75}\right.$ per d) with significant differences between diets $(P<0.01)$, due to slight differences in $\mathrm{ME}$ intake. Finally, most variables of the energy balance were affected by the individual sow, mostly due to important differences between sows in physical activity (Tables 3 and 4).

\section{Behaviour and physical activity of sows}

The energy cost of activity did not differ between diets within a sow $(P>0.05)$, but differed $(P<0.01)$ between sows; it ranged from 10 to $24 \% \mathrm{ME}$ intake (results not shown). Sows spent an average of $82 \%$ of the time lying down and a large proportion of the energy cost of activity (mean value $75 \%$ ) was measured during standing or sitting positions (Table 4). In addition, the energy cost of standing activity was linearly related to the time spent standing; the results show that the mean energy cost of standing activity averaged $0.25 \mathrm{~kJ} / \mathrm{kg} \mathrm{BW}^{0.75}$ per min standing (Fig. 2). The energy cost of activity during meal consumption (i.e. energy cost of eating) averaged $16 \%$ total activity HP. When expressed relative to the feed intake, the mean value was $348 \mathrm{~kJ} / \mathrm{kg}$ feed.

\section{Digestibility and metabolic utilisation of fibre-rich ingredients}

The lowest DC of organic matter or energy were observed for wheat bran, but these were not significantly different $(P>0.05)$ from those of maize bran or sugar-beet pulp (Table 5). The total tract DC of crude protein was variable between ingredients with the lowest value $(P<0.05)$ obtained for sugar-beet pulp. The digestibility of total DF was the lowest $(P<0.05)$ in wheat bran. The significance of the DC for crude fat was low for the three ingredients because of low concentrations of fat in maize bran and wheat bran and a close to zero concentration of fat in sugar-beet pulp.

The ME:DE ratio was more variable for the ingredients (Table 5) than for the diets (Table 3). For sugar-beet pulp, a value greater than $100 \%$ was estimated, which is due to the method of calculation when applied to ingredients low in crude protein. The DE values of wheat bran and sugarbeet pulp were similar $(12.3 \mathrm{MJ} / \mathrm{kg} \mathrm{DM})$ and were $1.7 \mathrm{MJ} /$ $\mathrm{kg}$ DM lower than DE values of maize bran (Table 4). On a ME or on a NE basis, the energy value for sugar-beet pulp was higher than for maize bran and wheat bran. However, the differences in energy values between ingredients were not significant (Table 5). 
Table 4. Physical activity of sows*

\begin{tabular}{|c|c|c|c|c|c|c|c|c|}
\hline \multirow[b]{2}{*}{ Item } & \multicolumn{4}{|c|}{ Diet } & \multirow[b]{2}{*}{ RSD } & \multicolumn{3}{|c|}{$P$ value for main effects $\dagger$} \\
\hline & C & MB & WB & SBP & & Animal & Diet & Period \\
\hline No. of observations & 4 & 4 & 4 & 4 & & & & \\
\hline \multicolumn{9}{|l|}{ Behaviour (min/d) } \\
\hline Standing & 277 & 235 & 236 & 261 & 33 & $<0.001$ & NS & NS \\
\hline Standing and eating & 30 & 37 & 33 & 30 & 5 & 0.008 & NS & 0.039 \\
\hline Standing and not eating & 247 & 198 & 203 & 231 & 37 & $<0.001$ & NS & NS \\
\hline Lying & 1163 & 1202 & 1204 & 1180 & 33 & $<0.001$ & NS & NS \\
\hline Rate of feed intake ( $\mathrm{g} / \mathrm{min})$ & 76 & 72 & 82 & 82 & 7 & $<0.001$ & NS & 0.003 \\
\hline \multicolumn{9}{|l|}{ Activity HP (MJ/d) } \\
\hline While standing & 3.88 & 3.59 & 3.81 & 4.09 & 0.36 & $<0.001$ & NS & NS \\
\hline Standing and eating & 0.77 & 0.91 & 0.82 & 0.76 & $0 \cdot 12$ & 0.006 & NS & NS \\
\hline Standing and not eating & $3 \cdot 12$ & $2 \cdot 68$ & 2.99 & 3.33 & 0.47 & $<0.001$ & NS & NS \\
\hline While lying & 1.03 & 1.34 & 1.02 & $1 \cdot 16$ & 0.31 & $<0.001$ & NS & NS \\
\hline Total & 4.91 & 4.94 & $4 \cdot 84$ & $5 \cdot 23$ & 0.45 & $<0.001$ & NS & NS \\
\hline Standing and eating HP (kJ/kg DM) & 341 & 394 & 334 & 336 & 46 & 0.002 & NS & 0.077 \\
\hline
\end{tabular}

C, control diet; MB, maize-bran supplemented diet; WB, wheat-bran supplemented diet; SBP, sugar-beet-pulp supplemented diet; RSD, residual standard deviation; HP, heat production.

* For details of diets and procedures, see Table 1 and p. 326.

†From ANOVA with effects of diet $(n 4)$, animal $(n 4)$ and period $(n 4)$.

\section{Discussion}

\section{Energy requirements of adult sows}

The fasting total HP $\left(260 \mathrm{~kJ} / \mathrm{kg} \mathrm{BW}^{0.75}\right.$ per d) measured in the present study was similar to the mean value of fasting HP obtained in the study of Noblet et al. (1993a), also conducted in ovariectomised sows. However, both estimates are lower than values obtained by Ramonet et al. (2000) in pregnant sows $\left(297-353 \mathrm{~kJ} / \mathrm{kg} \mathrm{BW}^{0.75}\right.$ per d between early and late pregnancy). The differences between nonpregnant and pregnant sows could be due to the priority requirement for growth of uterine tissues in fasted pregnant sows, with a subsequent HP due to metabolism of uterine tissues and the mobilisation of maternal body reserves for meeting this requirement.

The duration and the energy cost of standing activity was not different between the four experimental periods in the present study (Table 4). In other words, physical activity of sows was constant throughout the experiment, which means that this behaviour was typical for each sow. When expressed per unit metabolic BW, the mean value for energy cost of standing activity was $0.25 \mathrm{~kJ} / \mathrm{kg}$ $\mathrm{BW}^{0.75}$ per min standing (Fig. 2), which is close to the values found by Noblet et al. (1993b) and Cronin et al. (1986) in adult sows $\left(0.26\right.$ and $0.30 \mathrm{~kJ} / \mathrm{kg} \mathrm{BW}^{0.75}$ per min standing respectively). Differences between studies might be due to differences in the methods used for estimation of energy cost. As pointed out by Noblet et al. (1997), our results confirm the high and quite variable energy cost of physical activity in adult, non-lactating sows with subsequent consequences on the variability of energy requirements.

The ME requirement for maintenance $\left(\mathrm{ME}_{\mathrm{m}}\right)$ can be determined as $100 \times($ fasting $\mathrm{HP} / k$ ) plus energy for physical activity. Based on results of the present trial, the total $\mathrm{ME}_{\mathrm{m}}$ of the four sows averaged $387 \mathrm{~kJ} / \mathrm{kg} \mathrm{BW}^{0.75}$ per $\mathrm{d}$. The same approach used by Noblet et al. (1993a) indicates that, with moderate physical activity $\left(68 \mathrm{~kJ} / \mathrm{kg} \mathrm{BW}{ }^{0.75}\right.$ per d), $\mathrm{ME}_{\mathrm{m}}$ was approximately $400 \mathrm{~kJ} / \mathrm{kg} \mathrm{BW} \mathrm{BW}^{0.75}$ per $\mathrm{d}$ in adult non-pregnant sows. A similar value was obtained in non-pregnant sows in the study of Close et al. (1985) where $\mathrm{ME}_{\mathrm{m}}$ was obtained from regression equations between retained energy and energy intake. All these values are slightly lower than those obtained in pregnant sows $\left(440 \mathrm{~kJ} / \mathrm{kg} \mathrm{BW}^{0.75}\right.$ per d) in previous studies (Close et al. 1985; Ramonet et al. 2000). This difference between pregnant and non-pregnant sows has no clear interpretation and is not consistent with conclusions of a literature survey of Noblet et al. (1997) indicating that $\mathrm{ME}_{\mathrm{m}}$ was not affected by pregnancy nor by parity number of the sow.

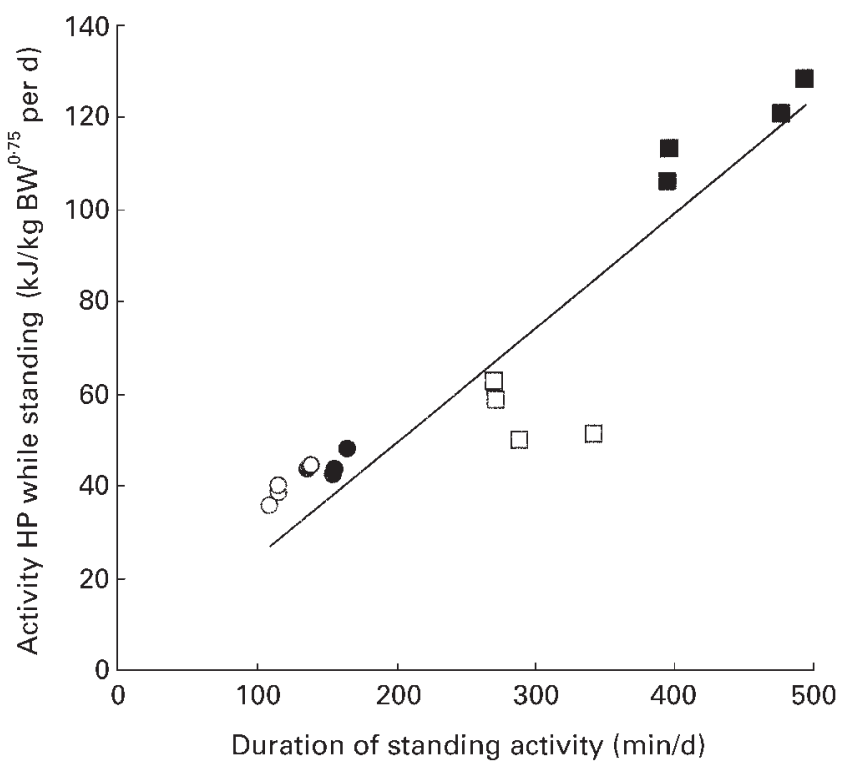

Fig. 2. Relationship between activity heat production while standing and time spent standing in adult sows $\left(y=0.25\right.$ (SE 0.01) $x, R^{2}$ $0.83)$. BW, body weight. $(\square)$, Sow A; $(\square)$, Sow B; $(\bullet)$, Sow C; $(O)$, Sow D). For details of diets and procedures, see Table 1 and $p$. 326. 
Table 5. Chemical composition and digestive and metabolic utilisation of maize bran, wheat bran and sugar-beet pulp in adult sows ${ }^{*} \dagger$

\begin{tabular}{|c|c|c|c|c|c|c|c|}
\hline & \multicolumn{3}{|c|}{ Ingredient } & \multirow[b]{2}{*}{ RSD } & \multicolumn{3}{|c|}{$P$ value for main effects $\ddagger$} \\
\hline & Maize bran & Wheat bran & Sugar-beet pulp & & Animal & Ingredient & Period \\
\hline \multicolumn{8}{|c|}{ Chemical composition (g/kg DM) } \\
\hline Ash & 28 & 65 & 82 & - & - & - & - \\
\hline Crude protein $(\mathrm{N} \times 6.25)$ & 162 & 170 & 100 & - & - & - & - \\
\hline Diethyl ether extract & 45 & 37 & 12 & - & - & - & - \\
\hline Crude fibre & 110 & 107 & 202 & - & - & - & - \\
\hline NDF & 495 & 425 & 447 & - & - & - & - \\
\hline ADF & 126 & 127 & 215 & - & - & - & - \\
\hline ADL & 18 & 42 & 30 & - & - & - & - \\
\hline Total DF & 482 & 432 & 705 & - & - & - & - \\
\hline WICW & 509 & 461 & 601 & - & - & - & - \\
\hline Starch & 243 & 168 & NA & - & - & - & - \\
\hline Sugars & 3 & 68 & 67 & - & - & - & - \\
\hline Energy (MJ/kg DM) & 19.59 & $18 \cdot 80$ & $16 \cdot 87$ & - & - & - & - \\
\hline \multicolumn{8}{|l|}{ Digestibility coefficient (\%) } \\
\hline Organic matter & $75 \cdot 5$ & $68 \cdot 9$ & $78 \cdot 4$ & 3.8 & NS & NS & NS \\
\hline Crude protein & $60^{\mathrm{a}}$ & $70^{\mathrm{a}}$ & $43^{b}$ & 8 & NS & 0.035 & NS \\
\hline Diethyl ether extract & 40 & 35 & NA & NA & NA & NA & NA \\
\hline Crude fibre & $56^{\mathrm{ab}}$ & $23^{\mathrm{b}}$ & $75^{\mathrm{a}}$ & 18 & NS & 0.065 & NS \\
\hline NDF & $73^{a}$ & $53^{\mathrm{b}}$ & $79^{\mathrm{a}}$ & 7 & NS & 0.035 & NS \\
\hline ADF & $65^{\mathrm{ab}}$ & $32^{\mathrm{b}}$ & $80^{\mathrm{a}}$ & 16 & NS & 0.052 & NS \\
\hline TDF & $70^{\mathrm{a}}$ & $52^{b}$ & $81^{a}$ & 8 & NS & 0.033 & NS \\
\hline Energy & $71 \cdot 3$ & $65 \cdot 4$ & $72 \cdot 9$ & $4 \cdot 6$ & NS & NS & NS \\
\hline Energy as methane (\% DE) & $3 \cdot 1$ & 0.7 & $3 \cdot 8$ & 1.6 & 0.061 & NS & NS \\
\hline $\mathrm{ME} / \mathrm{DE}$ & $89 \cdot 7^{b}$ & $97 \cdot 3^{\mathrm{ab}}$ & $102 \cdot 9^{a}$ & 3.8 & 0.020 & 0.036 & NS \\
\hline NE/ME & $86 \cdot 4$ & $82 \cdot 8$ & 91.4 & $13 \cdot 8$ & NS & NS & NS \\
\hline $\mathrm{NE} / \mathrm{DE}$ & $77 \cdot 2$ & $81 \cdot 2$ & $95 \cdot 3$ & 13.9 & NS & NS & NS \\
\hline \multicolumn{8}{|l|}{ Energy values (MJ/kg DM) } \\
\hline $\mathrm{DE}$ & 13.97 & $12 \cdot 29$ & $12 \cdot 30$ & 0.78 & NS & NS & NS \\
\hline ME & $12 \cdot 53$ & $12 \cdot 00$ & $12 \cdot 77$ & 1.03 & NS & NS & NS \\
\hline NE & $10 \cdot 71$ & 9.90 & 11.62 & $2 \cdot 23$ & NS & NS & NS \\
\hline
\end{tabular}

RSD, residual standard deviation; NDF, neutral-detergent fibre; ADF, acid-detergent fibre, ADL, acid-detergent lignin; DF, dietary fibre; WICW, water-insoluble cell walls; DE, digestible energy; ME, metabolisable energy; NE, net energy; NA, not applicable.

a,b,c,d Mean values within a row with unlike superscript letters were significantly different, $P<0.05$.

* For details of diets and procedures, see Table 1 and p. 326.

† Digestibility coefficients and energy values of ingredients were determined according to the difference method (Noblet \& Shi, 1994); it is supposed that, for each sow, the digestive utilisation of the control diet is the same in the fibre-rich diets.

‡From ANOVA with effects of ingredient $(n 3)$, animal $(n 4)$ and period $(n 4)$. Diethyl ether extract of faeces was measured on samples pooled per diet and per pig stage and corresponding DC could not be submitted to the ANOVA.

\section{Digestibility of dietary fibre in adult sows}

It has been well illustrated in the current study that the introduction of a fibre-rich ingredient to the control diet reduced the apparent digestibility of DM, nutrients and energy to variable extents according to the botanical origin of DF. This is related to the higher digestibility of energy for SBP diet than for WB diet. Similar conclusions were obtained in growing pigs (Graham et al. 1986; Chabeauti et al. 1991) or in adult sows (Yan et al. 1995). Supplementing the basal diet with maize bran or wheat bran caused higher faecal $\mathrm{N}$ losses. This result may be explained by increased endogenous secretions or a greater microbial activity in the hindgut with higher faecal excretion of $\mathrm{N}$ incorporated in microbial protein (Kirchgessner et al. 1994). In addition, the differences in digestibility of diets were mainly related to the digestibility of the fibre fraction (Table 5); digestibility of the fibre fraction from wheat bran was lower than digestibility of the fibre fraction from sugar beet (and maize bran to a smaller extent). The extent of degradation of the fibre fraction can be explained by structural differences (Noblet \& Bach Knudsen, 1997). First, lignified fibre sources such as wheat bran are degraded only to a small extent (Bach Knudsen \& Hansen, 1991). In contrast, the high level of pectic polysaccharides and the great pore volume of sugar-beet pulp facilitate its degradation (Guillon et al. 1998). Fibre from maize bran is less lignified compared with wheat bran and subsequently more digestible. Due to the structure of polysaccharides, the maize-bran cell walls are more resistant to degradation than those of sugar-beet pulp (Saulnier \& Thibault, 1999).

Utilisation of fibre results in the formation of $\mathrm{CH}_{4}$ during fermentation in the hindgut. In the present study, it averaged $1.1 \% \mathrm{DE}$ and was close to the mean value recorded by Noblet \& Shi (1993) in maintenance-fed adult sows. In addition, results of the present study indicate that energy losses as $\mathrm{CH}_{4}$ were increased by approximately $1.4 \mathrm{~kJ}$ for each additional $\mathrm{g}$ digestible total DF in the diet (Fig. 1). In order to compare this result with those of previous studies, results in the literature on $\mathrm{CH}_{4}$ production in adult sows are presented in Fig. 3 (Shi, 1993; Ramonet et al. 2000; Jørgensen et al. 2001; Olesen et al. 2001; Rijnen et al. 2001). According to a covariance analysis, 


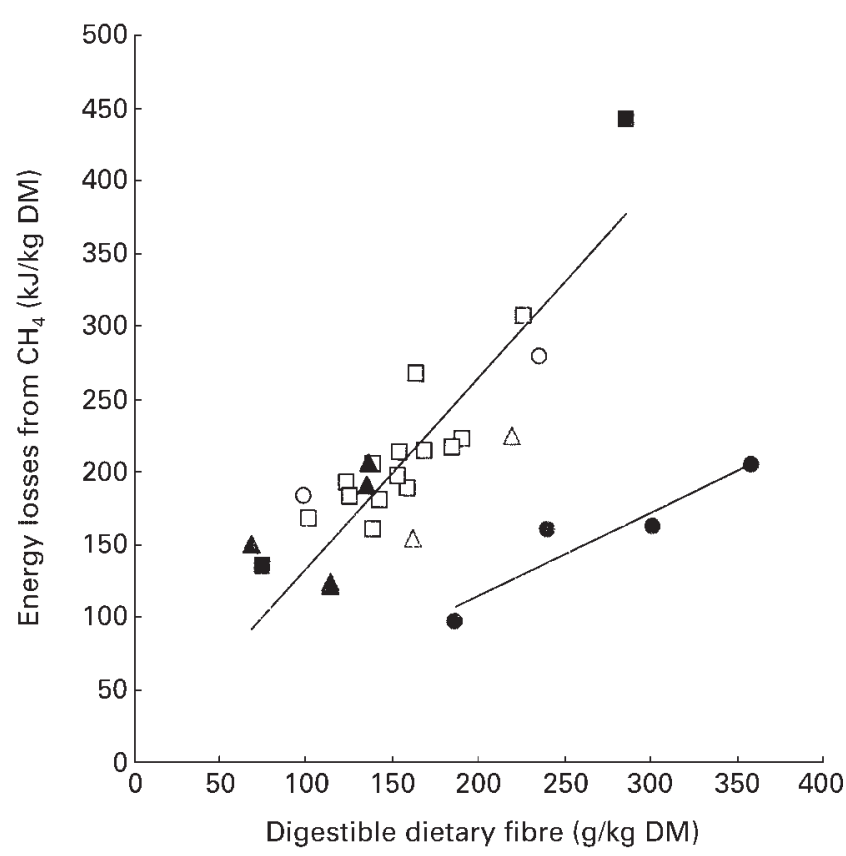

Fig. 3. Relationships between energy losses from methane and digestible dietary fibre intake; digestible dietary fibre is calculated as the difference between organic matter and the sum of digestible crude protein, digestible diethyl ether extract, starch and sugars ( $\square$ ), Shi (1993); (ם), Ramonet et al. (2000); ( $\triangle$ ), Jørgensen et al.

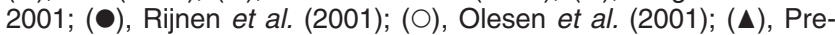
sent study. According to a covariance model with digestible dietary fibre as a covariate and study as a fixed effect, the slope obtained with the results from the study of Rijnen et al. (2001) was significantly $(P<0.01)$ different from those of the other studies. Accordingly, two regression equations were obtained, one with the results of Rijnen et al. (2001) ( $y=0.58$ (SE 0.03) $\left.x, R^{2} 0.88, n 4\right)$ the second one with the other results $\left(y=1.33\right.$ (SE 0.04) $\times R^{2} 0.71, n$ 25).

the relationship between energy losses as $\mathrm{CH}_{4}$ and digestible DF obtained with results of Rijnen et al. (2001) ( $n$ 4) is different from the relationship obtained with the results ( $n$ 25) of Shi (1993), Jørgensen et al. (2001), Ramonet et al. (2000) and Olesen et al. (2001). The relationship obtained with these last four studies is close to the result of the present study with an increase of $1.3 \mathrm{~kJ}$ energy from $\mathrm{CH}_{4}$ for each $\mathrm{g}$ additional digestible $\mathrm{DF}$ in the diet (Fig. 3). One gram digestible DF is equivalent to $18.1 \mathrm{~kJ}$ according to an equation proposed by Le Goff \& Noblet (2001). Consequently, energy loss as $\mathrm{CH}_{4}$ represents about $7 \%$ (i.e. $1 \cdot 3 / 18 \cdot 1 \mathrm{~kJ} \times 100$ ) of the energy of digestible DF. This result is slightly higher than the value (4-5\%) reported by Noblet \& Le Goff (2001). According to the relationship obtained with the data of Rijnen et al. (2001), energy loss as $\mathrm{CH}_{4}$ would represent $3 \%$ of the energy of digestible DF. Differences between studies are not fully understood; they may depend on the botanical origin of DF or on the methodology used for $\mathrm{CH}_{4}$ measurements or chemical composition of diets determination.

The energy values of diets were used to determine DE or ME values of ingredients according to the difference method (Noblet \& Shi, 1994). All values were close to those measured in adult non-pregnant and non-lactating sows by Noblet \& Bourdon (1997); in addition, they were systematically greater than those proposed in feeding tables (Central Veevoederbureau, 1998). The Central Veevoederbureau values are based largely on results obtained in growing pigs. The higher values reported in the present study are mainly explained by the greater intestinal capacity of adult animals to utilise DF (Noblet \& Shi, 1993).

\section{Dietary fibre and metabolic energy utilisation of diets in adult sows}

In agreement with observations of Ramonet et al. (2000), fasting $\mathrm{HP}$ and $\mathrm{TEF}_{\mathrm{st}}$ were not affected by the addition of DF in the diet; our present study also shows that the botanical origin of DF had no effect on fasting HP and $\mathrm{TEF}_{\text {st. }}$. In addition, activity HP was not affected by the introduction of a fibrous ingredient in the control diet. This observation does not confirm previous results, which show that fibrous diets can reduce standing activity in sows housed in a piggery or energy expenditure due to physical activity in group-housed pigs (Schrama et al. 1998; Ramonet et al. 1999). This may be due to the fact that, in the present study, sows were kept alone in the respiration chamber and were completely isolated from the environment. In connection with the absence of effect of diet composition on main components of HP, total HP was not affected by the addition of DF in the diet. This result contrasts with previous studies, which showed an increased heat increment with the DF level in growing pigs (Jørgensen et al. 1996) or in adult sows (Noblet et al. 1993a; Ramonet et al. 2000; Olesen et al. 2001). In fact, the variation of DF level between the control and the DF-rich diet was low $(90 \mathrm{~g} \mathrm{DF} / \mathrm{kg} \mathrm{DM})$ when compared with those of the latter studies (approximately $200 \mathrm{~g} \mathrm{DF} / \mathrm{kg}$ $\mathrm{DM})$. Therefore, the absence of variation in total HP between the control diet and the other three diets may be explained by the low variation in DF level between diets. However, the energetic efficiency of dietary energy arising from fermentation is expected to be lower than that of carbohydrates, which are absorbed as monosaccharides in the small intestine, due to energy losses as $\mathrm{CH}_{4}, \mathrm{H}_{2}$ and heat of fermentation, and a lower biochemical efficiency of volatile fatty acids (Dierick et al. 1989). In practical terms, this means that HP of pigs fed the same daily DE or ME should increase with DF content of the feed. As it was not the case in the present study, it can be hypothesised that the presence of DF in the diets has modified the metabolism of the sows with a subsequent lower HP. These hypothetical modifications could have compensated for the expected HP increase.

Total HP was not affected by the botanical origin of fibre included in the diet. Comparable information on metabolic utilisation of fibre-rich diets in the literature is scarce. However, the present findings are consistent with another study where a similar total HP was measured in pregnant sows fed a WB diet or a SBP diet, both diets supplying equal amounts of DF (Jørgensen et al. 2001). Results on SBP diet are in agreement with those of Rijnen et al. (2001), who showed that total HP was unaffected by the exchange of starch from a control diet by fibre from sugar-beet pulp silage in group-housed sows. In the present 
study, the similar HP for the control diet and SBP diet can be related to a similar TEF (12\% ME intake) or, more precisely, with a similar $\mathrm{TEF}_{\mathrm{lt}}(1.2 \% \mathrm{ME}$ intake). In fact, $\mathrm{TEF}_{\text {lt }}$ represents long-term metabolic phenomena such as metabolism and fermentation (Ramonet et al. 2000). Therefore, the absence of effect of additional sugar-beet pulp on HP might be explained by the ability of sows to use fermented DF from sugar-beet pulp as efficiently as energy from digested starch of the control diet. In contrast, the TEF associated with ingestion and digestion of diet WB was higher than with the other three diets, in relation to a higher $\mathrm{TEF}_{1 \mathrm{t}}$. One hypothesis for this higher TEF of wheat bran would be an increased energy cost of digestion and excretion of undigested material (Table 2), which is higher for diet WB. This result can be mainly explained by a greater resistance of wheat-bran fibre to degradation by bacteria in the hindgut of pigs (Bach Knudsen \& Canibe, 2000).

\section{Conclusion}

The present study indicates that the introduction of a fibrous ingredient in a basal diet reduced the digestibility of energy and nutrients in adult non-pregnant and non-lactating sows. This effect was more pronounced with wheat bran than with maize bran or sugar-beet pulp. The use of a diet that included wheat bran induced a higher TEF than those containing maize bran or sugar-beet pulp. However, these effects on TEF have negligible consequences on the total HP or energy balance of sows. Finally, our study indicates large individual animal variation on the energy balance mainly due to behavioural differences.

\section{Acknowledgements}

The authors thank the GERNA (Paris) for financial support. The authors gratefully acknowledge P. Bodinier, S. Hillion and A. Roger for their technical assistance in animal care and chemical analyses.

\section{References}

Association of Official Analytical Chemists (1990) Official Methods of Analysis, 15th ed. Washington DC: AOAC.

Bach Knudsen KE \& Canibe N (2000) Breakdown of plant carbohydrates in the digestive tract of pigs fed on wheat- or oatbased rolls. Journal of the Science of Food and Agriculture 80, 1261.

Bach Knudsen KE \& Hansen JA (1991) Gastrointestinal implications in pigs of wheat and oat fractions I. Digestibility and bulking properties of polysacharides and other major constituents. British Journal of Nutrition 65, 217-232.

Bureau Interprofessionel d'Etudes Analytiques (1976) Recueil des méthodes d'analyse des Communautés Européennes (Analytical methods in the European Community) pp. 105-111. Gennevilliers: BIPEA.

Brouns F, Edwards SA \& English PR (1995) Influence of fibrous feed ingredients on voluntary intake of dry sows. Animal Feed Science and Technology 54, 301-313.

Brouwer E (1965) Report of sub-committee on constants and factors. In Energy Metabolism. Proceedings of the 3rd Symposium held at Troon, Scotland, May, 1964. European Association for
Animal Production Publication no. 11, pp. 441-443 [KL Blaxter, editor]. London: Academic Press.

Carré B \& Brillouet JM (1986) Yield and composition of cell wall residues isolated from various feedstuffs used for non-ruminant farm animal. Journal of the Science of Food and Agriculture 37, 341-351.

Chabeauti E, Noblet J \& Carré B (1991) Digestion of plant cell walls from four different sources in growing pigs. Animal Feed Science and Technology 32, 207-213.

Close WH, Noblet J \& Heavens RP (1985) Studies on the energy metabolism of the pregnant sow. 2. The partition and utilization of metabolizable energy intake in pregnant and non-pregnant animals. British Journal of Nutrition 53, 267-279.

Cronin GM, van Tartwijk MFM, van der Hel W \& Verstegen MWA (1986) The influence of degree of adaptation to tetherhousing by sows in relation to behaviour and energy metabolism. Animal Production 42, 257-268.

Central Veevoederbureau (1998) Veevoedertabel (Feeding Tables). Leylystad: Central Veevoederbureau in Nederland.

Dierick NA, Vervaeke IJ, Demeyer DI \& Decuypere JA (1989) Approach to the energetic importance of fibre digestion in pigs. 1. Importance of fermentation in the overall energy supply. Animal Feed Science and Technology 23, 141-167.

Etienne M (1987) Utilization of high fibre feeds and cereals by sows. Livestock Production Science 16, 229-242.

Etienne M, Noblet J, Dourmad JY \& Castaing J (1997) Digestive utilization of feeds in lactating sows. Comparison with growing pigs. In Digestive Physiology in Pigs, pp. 583-586 [JP Laplace, C Février and A Barbeau, editors]. Saint-Malo: INRA.

European Economic Community (1972) Analytical determination of starch. In Official Journal of European Communities L123/7. Brussels: EEC.

Graham H, Hesselman K \& Åman P (1986) The influence of wheat bran and sugar-beet pulp on the digestibility of dietary components in a cereal-based pig diet. Journal of Nutrition 116, $242-251$.

Guillon F, Auffret A, Robertson JA, Thibault JF \& Barry JL (1998) Relationships between physical characteristics of sugar-beet fibre and its fermentability by human faecal flora. Carbohydrate Polymers 37, 185-197.

Jørgensen H, Bach Knudsen KE \& Theil PK (2001) Effect of dietary fibre on energy metabolism of growing pigs and pregnant sows. In Energy Metabolism in Animals, European Association for Animal Production Publication no. 103, pp. 105-108 [A Chwalibog and K Jakobsen, editors]. Wageningen: Wageningen Pers.

Jørgensen H, Zhao XQ \& Eggum BO (1996) The influence of dietary fibre and environmental temperature on the development of the gastrointestinal tract, digestibility, degree of fermentation in the hind-gut and energy metabolism in pigs. British Journal of Nutrition 75, 365-378.

Kirchgessner M, Kreuzer M, Machmüller A \& Roth-Maier DA (1994) Evidence for a high efficiency of bacterial protein synthesis in the digestive tract of adult sows fed supplements of fibrous feedstuffs. Animal Feed Science and Technology 46, $293-306$.

Lawrence AB \& Terlouw EMC (1993) A review of behavioral factors involved in the development and continued performance of stereotypic behaviors in pigs. Journal of Animal Science 71, 2815-2825.

Le Goff G \& Noblet J (2001) Comparative total tract digestibility of dietary energy and nutrients in growing pigs and adult sows. Journal of Animal Science 79, 2418-2427.

Noblet J \& Bach Knudsen KE (1997) Comparative digestibility of wheat, maize and sugar beet pulp non-starch polysaccharides in adult sows and growing pigs. In Digestive Physiology in Pigs, European Association for Animal Production Publication no. 
88, pp. 571-574 [JP Laplace, C Février and A Barbeau, editors]. Saint-Malo: INRA.

Noblet J \& Bourdon D (1997) Valeur énergétique comparée de onze matières premières chez le porc en croissance et la truie adulte (Comparative energy values of eleven feedstuffs in growing pigs and adult sows). Journées de la Recherche Porcine en France 29, 221-226.

Noblet J, Dourmad JY, Etienne M \& Le Dividich (1997) Energy metabolism in pregnant sows and newborn pigs. Journal of Animal Science 75, 2708-2714.

Noblet J, Fortune H, Dubois S \& Henry Y (1989) Nouvelles Bases d'Estimation des Teneurs en énergie Digestible, Métabolisable et Nette des Aliments pour le Porc (New approaches for estimating digestible, metabolisable and net energy values in pig feeds). Paris: INRA.

Noblet J \& Le Goff (2001) Effect of dietary fibre on the energy value of feeds for pigs. Animal Feed Science and Technology 90, 35-52.

Noblet J \& Shi XS (1993) Comparative digestibility of energy and nutrients in growing pigs fed ad libitum and adult sows fed at maintenance. Livestock Production Science 34, 137-152.

Noblet J \& Shi XS (1994) Effect of body weight on digestive utilization of energy and nutrients of ingredients and diets in pigs. Livestock Production Science 37, 323-338.

Noblet J, Shi XS \& Dubois S (1993a) Metabolic utilization of dietary energy and nutrients for maintenance energy requirements in sows: basis for a net energy system. British Journal of Nutrition 70, 407-419.

Noblet J, Shi XS \& Dubois S (1993b) Energy cost of standing activity in sows. Livestock Production Science 34, 127-136.

Olesen CS, Jørgensen H \& Danielsen V (2001) Effect of dietary fibre on digestibility and energy metabolism in pregnant sows. Acta Agricultura Scandinavica 51, 200-207.

Prosky L, Asp NG, Schweizer TF, DeVries JW \& Furda I (1988) Determination of insoluble, soluble, and total dietary fiber in foods and food products: Interlaboratory study. Journal of the Association of Official Analytical Chemists 71, 1017-1023.

Ramonet Y, Meunier-Salaün MC \& Dourmad JY (1999) Highfiber diets in pregnant sows: digestive utilization and effects on behavior of the animals. Journal of Animal Science 77, 591-599.

Ramonet Y, van Milgen J, Dourmad JY, Meunier-Salaün MC \& Noblet J (2000) The effect of dietary fibre on energy utilisation and partitioning of heat production over pregnancy in sows. British Journal of Nutrition 84, 85-94.
Rijnen MMJA, Verstegen MWA, Heetkamp MJW, Haaksma J \& Schrama JW (2001) Effect of dietary fermentable carbohydrates on energy metabolism in group-housed sows. Journal of Animal Science 79, 148-154.

Saulnier L \& Thibault JF (1999) Ferulic acid and diferulic acids as components of sugar-beet pectins and maize bran heteroxylans. Journal of the Science of Food and Agriculture 79, 396-402.

Schrama JW, Bosch MW, Verstegen MWA, Vorselaars AHPM, Haaksma J \& Heetkamp MJW (1998) The energetic value of nonstarch polysaccharides in relation to physical activity in group-housed, growing pigs. Journal of Animal Science 76, 3016-3023.

Schrama JW, Verstegen MWA, Verboeket PHJ, Schutte JB \& Haaksma J (1996) Energy metabolism in relation to physical activity in growing pigs as affected by type of dietary carbohydrate. Journal of Animal Science 74, 2220-2225.

Shi XS (1993) Effect of body weight or physiological status on digestive and metabolic utilization of energy in pigs. $\mathrm{PhD}$ Thesis, University of Rennes I.

van Milgen J \& Noblet J (2000) Modelling energy expenditure in pigs. In Modelling Nutrient Utilization in Farm Animals, pp. 103-114 [JP McNamara, J France and DE Beever, editors]. Oxford: CABI Publishing.

van Milgen J, Noblet J, Dubois S \& Bernier JF (1997) Dynamic aspects of oxygen consumption and carbon dioxide production in swine. British Journal of Nutrition 78, 397-410.

Van Soest PJ \& Wine RH (1967) Use of detergents in the analysis of fibrous feeds. IV. Determination of plant cell-wall constituents. Journal of the Association of Official Analytical Chemists 50, 50-55.

Vermorel M, Bouvier JC, Bonnet Y \& Fauconneau G (1973) Construction et fonctionnement de 2 chambres respiratoires du type $\ll$ circuit ouvert $\gg$ pour jeunes bovins (Construction and operation of two open-circuit respiration chambers for young cattle). Annales de Biologie Animale, Biochimie, Biophysique 13, 659-681.

Whittemore CT, Smith WC \& Phillips P (1988) Fatness, live weight and performance responses of food level in pregnancy. Animal Production 47, 123-130.

Yan T, Longland AC, Close WH, Sharpe CE \& Keal HD (1995) The digestion of dry matter and non-starch polysaccharides from diets containing plain sugar-beet pulp or wheat straw by pregnant sows. Animal Science 61, 305-309. 